\section{Yield of Four Generations of Virus-tested Sweetpotato}

\author{
D. La Bonte ${ }^{1}$, C. Clark²,
} A. Villordon ${ }^{3}$, J. Cannon ${ }^{3}$, M. $\mathrm{Hoy}^{2}$, M. Sistrunk ${ }^{4}$, E. Freeman ${ }^{4}$, and G. Roberts ${ }^{4}$

AdDitional INDEX wORDs. Ipomoea batatas, propagation, virus-tested, viruses

Summary. The yield of three generations of virus-tested plants of 'Beauregard' sweetpotato (Ipomoea batatas) was assessed in Louisiana over a 4-year period in $\mathbf{1 5}$ yield trials. Treatments included virus-infected foundation 'Beauregard', virus-tested 'Beauregard' mericlone, B-63 [generation 1 $(\mathrm{G}-1)]$, and three generations of B-63 (G-2, G-3 and G-4). Generations refer to the number of continuous years virus-tested plants are grown in the field. Use of G-2 virus-tested 'Beauregard' transplants increased yields of U.S. no. 1 grade roots by $16 \%$ in comparison with virus-infected, foundation 'Beauregard'. Total marketable yield was also higher (11\%) using B-63 G-2 transplants in comparison to virus-infected, foundation 'Beauregard'. Use of B-63 (G-1), G-3 and G-4 generation transplants did not increase yields in any grade in comparison to virus-infected, foundation 'Beauregard' by planting plots amidst virus-infested sweetpotato fields. Generation one B-63 transplants were greenhouse grown and often appeared less robust after planting. Yet we were

This research was supported by funds from the Louisiana Sweet Potato Advertising and Development Commission (LSPADC), and by state and matching funds allocated to the Louisiana State University Agricultural Center (LSUAC).

${ }^{1}$ Department of Horticulture, Louisiana State University Agricultural Center, Louisiana Agricultural Experiment Station, Baton Rouge, LA 70803. To whom reprint requests should be sent. E-mail: dlabonte@agctr.lsu.edu

${ }^{2}$ Department of Plant Pathology and Crop Physiology, Louisiana State University Agricultural Center, Louisiana Agricultural Experiment Station, Baton Rouge, LA 70803.

${ }^{3}$ Sweet Potato Research Station, Louisiana State University Agricultural Center, Chase, LA 71324.

${ }^{4}$ Louisiana Cooperative Extension Service, Louisiana State University Agricultural Center, Baton Rouge, LA 71324 unable to show significant yield differences between greenhouse derived B-63 (G-1) and field-grown B-63 (G$1)$ in separate tests; other factors may be involved.

S weetpotato growers rely upon state foundation seed programs to provide genetically uniform seed stock free of major diseases. Growers normally purchase one $40-\mathrm{lb}$ box of foundation seed per acre $(44.8$ $\mathrm{kg} \cdot \mathrm{ha}^{-1}$ ) of production field they plan to produce. Plants arising from this box of seed are increased in field plantings over 2 years before using it as the actual bedding stock for production purposes.

Until the mid- to late 1990s, foundation seed was sold in the United States containing the detectable potyvirus sweet potato feathery mottle virus (SPFMV). Viruses present in the United States were not viewed, except for the SPFMV strain causing russet crack (Moyer and Clark, 1988), as factors affecting yield and quality. Strains of SPFMV and other viruses in general were simply not identified as extant in the U.S., unknown, or considered as anomalies when discovered; however, it has become evident that several viruses exist in the United States and yield reductions as great as $30 \%$ to $50 \%$ have been measured in 'Beauregard' that were graft inoculated with virus-infected plants (Clark, $2001)$. For example, sweet potato virus G (SPVG), and ipomoea vein mosaic virus (IVMV) are both potyviruses only recently documented (Souto et al., 2003). Lighter flesh color and poor root shape are also being attributed to virus infections (Bryan et al., 2003a; Carroll et al., 2004). In hindsight, our foundation seed may have contained a panoply of viruses at unknown levels. Virus surveys of major U.S. production regions are needed to document distribution and occurrence.

As a result of new insights regarding viruses, foundation seed programs have modified their practices since the mid to late-1990s to using virus-tested vine cuttings and seed roots for distribution to growers. Prices have risen modestly for foundation seed stock to cover added expenses, e.g., from $\$ 12$ to $\$ 14-\$ 15$ in Louisiana for a $40-1 b$ $(18.1 \mathrm{~kg})$ box $(\$ 0.66 / \mathrm{kg}$ to $\$ 0.77 /$ $\mathrm{kg}-\$ 0.83 / \mathrm{kg})$. The seed program supports $\sim 20,000$ production acres $(8094$ ha) in Louisiana for a crop valued at $\sim 86$ million (value added included) and ranked as the most important vegetable crop in the state.

Greater management inputs are needed with virus-tested planting material, i.e., increase fields need to be isolated from virus-infected production fields and kept free of aphids and white flies to minimize re-infection. The rate of re-infection by viruses of sweetpotatoes in the field can vary greatly from year to year, but is commonly very rapid. In several instances, small plots of virus-tested plants in large fields of infected plants have become 100\% reinfected with sweet potato feathery mottle virus within the first year (Bryan et al., 2003b; C.A. Clark, unpublished). Unfortunately, growers have yet to adopt adequate isolation practices potentially mitigating beneficial aspects of virus-tested sweetpotato.

The perception among growers is that using virus-tested plants should improve yields vs. plants from traditional virus-infected foundation seed. Yet, no data has been presented documenting actual yield performance. Our objective in this study was to compare yield of virus-tested plants over several generations to that of traditional virus-infected foundation plants among virus-infected plantings.

\section{Materials and methods}

Yield TRIALS. Effect of virustested transplants on yield was assessed in Louisiana in 1996, 1997, 1998, and 1999 in 15 yield trials. Yield trials were at the Sweet Potato Research Station at Chase ( 5 trials) and various Louisiana farms (10 trials). Treatments included transplants of virus-infected foundation 'Beauregard', virus-tested 'Beauregard', mericlone B-63, and three generations of B-63 (G-2, G-3, and G-4). The treatments in 1996 included B-63 and virus-infected foundation 'Beauregard'. In each subsequent year, an additional generation was added, e.g., 1997 included B-63, virus-infected foundation 'Beauregard', and G-2. Seed from the various generations was saved for subsequent year testing at random. Virus-infected foundation 'Beauregard' were plants that became naturally infected during traditional foundation seed production in the field (Miller et al., 1959), prior to the advent of virus-tested seed that has been produced since 1999. Virustested plants were initially produced 
by meristem-tip culture followed by indexing on indicator plants. Virustested plants, i.e., plants free of known, detectable viruses, are increased in vitro and multiplied in insect resistant greenhouses for field transplanting. Generations refer to the number of continuous years virus-tested plants are grown in the field. Virus-tested B-63 from the greenhouse is referred to as G- 1 in this study. All treatments were transplanted in early May to late June. Twenty transplants per plot were placed $1 \mathrm{ft}(0.3 \mathrm{~m})$ apart within rows and 3 to $4 \mathrm{ft}(0.9-1.2 \mathrm{~m})$ between rows in a randomized complete-block design with three to four replications. Commercial sweetpotato cultural practices were followed (Boudreaux, 1994). Roots were harvested 80 to $141 \mathrm{~d}$ after transplanting. Harvest date varied greatly depending on planting date and growth conditions. Yield was calculated in number of 50-1b $(22.7$ $\mathrm{kg}$ ) bushels per acre $(1 \mathrm{bu} / \mathrm{acre}=56.0$ $\mathrm{kg} \cdot \mathrm{ha}^{-1}$ ) for the following categories: U.S. no. 1 grade roots [roots 2 to 3.5 inches $(5.1-8.9 \mathrm{~cm})$ diameter, and 3 to 9 inches $(7.6-22.9 \mathrm{~cm})$ long ]; canner [roots 1 to 2 inches $(2.5-5.1 \mathrm{~cm})$ diameter, and 2 to 7 inches (5.1-17.8 $\mathrm{cm}$ ) long]; and jumbo (larger than either of the other categories, but marketable). Total marketable yield (U.S. no. I + canner + jumbo) was also measured. All data were analyzed by PROC MIXED of SAS (SAS Institute, Cary, N. C.). Year and location were considered random and hence included in the variance estimates. Least squares means for each variable were separated using a $t$ test at $P \leq 0.05$.

\section{Results and discussion}

Greenhouse-grown B-63 (G-1) did not yield differently in any grade in comparison to virus-infected, foundation 'Beauregard' (Table 1). These results ran counter to our expectations. Our initial hypothesis was that greenhouse grown transplants were less robust and yield was thusly compromised, but a yield trial in 2001 and two in 2002 comparing greenhouse derived B-63 (G-1) and field grown B-63 (G-1) transplants did not show significant differences (data not shown). Our results differ from those of Bryan et al. (2003a). They found G-1 plants from a different clone (B14) had higher yield in comparison to a non-virus indexed 'Beauregard' stock in North Carolina. The present study used the B-63 clone, which has lower yield characteristics than the $\mathrm{B}-14$ clone (Villordon et al., 2003). This may account for our nonsignificant results. The non-virus indexed 'Beauregard' stock used by Bryan et al. (2003a) may also have lower yield potential than the foundation 'Beauregard' clone used in the present study. Use of G-2, B-63 transplants increased yields of U.S. no. 1 grade roots by $16 \%$ in comparison to virus-infected, foundation 'Beauregard' (Table 1). These results are consistent with Bryan et al. (2003). In these trials, all transplant stocks (G-2 and later) were derived from field beds. Total marketable yield was also significantly higher for G-2 transplants (11\%) in comparison to foundation 'Beauregard', while no significant difference was found for canner and jumbo grades. Use of G-3 and G-4 transplants did not differ for yield in any grade in comparison to virus-infected, foundation 'Beauregard'. Symptoms consistent with russet crack were not found in any treatment, eliminating our need for the USDA cull grade category; however, a similar study in other U.S. production areas with higher incidences of russet crack could show an increase in later generation roots. Culls can also represent severely misshapen roots unacceptable as canners; we did not encounter any appreciable number.

Economically, a $16 \%$ increase in yield of U.S. no. I would equate to a $40 \mathrm{bu} /$ acre $\left(2242 \mathrm{~kg} \cdot \mathrm{ha}^{-1}\right)$ increase in yields [given a $250 \mathrm{bu} /$ acre $(14,010$ $\mathrm{kg} \cdot \mathrm{ha}^{-1}$ ) base]. A gain of $\$ 320 /$ acre $(\$ 790.71 /$ ha $)$ would be realized at an
$\$ 8.00 /$ bu price $(\$ 0.35 / \mathrm{kg})$. A caveat to these calculations is that the yield gain is in the second year of increase and does not extend to the next year when the seed is actually used for producing the marketable crop.

In conclusion, sweetpotato yield was likely compromised by the G-3 generation by planting virus-tested transplants in fields among virusinfested sweetpotatoes. The present work does not directly implicate specific viruses nor document reinfection rates, but does indicate relative yield veracity when virus-tested sweetpotato is grown among virus-infected plants for a number of generations. Adequate isolation and vector control may extend yield potential to the G-3 generation and beyond.

\section{Literature cited}

Boudreaux, J.E. 1994. Commercial vegetable production recommendations. Louisiana Coop. Ext. Serv. Publ. 2433.

Bryan , A.D. Z. Pesic-VanEsbroeck, J.R. Schultheis, K.V. Pecota, W.H. Swallow, and G.C. Yencho. 2003a. Cultivar decline in sweetpotato: I. impact of micropropagation on yield, storage root quality, and virus incidence in 'Beauregard'. J. Amer. Soc. Hort. Sci. 128:846-855.

Bryan, A.D., J.R. Schultheis, Z. PesicVanEsbroeck, and G.C. Yencho. 2003b. Cultivar decline in sweetpotato II. Impact of virus infection on yield and storage root quality in 'Beauregard' and 'Hernandez'. J. Amer. Soc. Hort. Sci. 128:856-863.

Carroll, H.W., A.Q. Villordon, C.A. Clark, D.R. La Bonte, and M.W. Hoy. 2004. Studies on Beauregard sweetpotato clones naturally infected with viruses. Intl. J. Pest Mgt. (In press.)

Table 1. Comparison of virus-tested 'Beauregard' B-63 mericlone (selection) sweetpotato transplants in 15 yield trials over four generations in comparison to virus-infected 'Beauregard' foundation transplants on root yield.

\begin{tabular}{lcccc}
\hline & \multicolumn{4}{c}{ Yield [no. 50-1b (22.7 kg) bu/acre] } \\
\cline { 2 - 5 } Clonal treatment $^{\mathbf{z}}$ & U.S. \# 1 & Canner & Jumbo & Total marketable \\
\hline Foundation & & & & \\
$\quad$ 'Beauregard' $(15)^{\mathrm{x}}$ & $344 \pm 31 \mathrm{~b}^{\mathrm{w}}$ & $153 \pm 12 \mathrm{a}$ & $60 \pm 17 \mathrm{a}$ & $556 \pm 44 \mathrm{~b}$ \\
B-63 G-1 (8) & $335 \pm 33 \mathrm{~b}$ & $138 \pm 14 \mathrm{a}$ & $67 \pm 18 \mathrm{a}$ & $538 \pm 46 \mathrm{~b}$ \\
B-63 G-2 (12) & $407 \pm 31 \mathrm{a}$ & $151 \pm 13 \mathrm{a}$ & $65 \pm 17 \mathrm{a}$ & $622 \pm 45 \mathrm{a}$ \\
B-63 G-3 (9) & $356 \pm 33 \mathrm{~b}$ & $142 \pm 14 \mathrm{a}$ & $67 \pm 18 \mathrm{a}$ & $564 \pm 46 \mathrm{~b}$ \\
B-63 G-4 (5) & $350 \pm 35 \mathrm{~b}$ & $132 \pm 17 \mathrm{a}$ & $60 \pm 20 \mathrm{a}$ & $541 \pm 49 \mathrm{~b}$ \\
\hline
\end{tabular}

${ }^{2}$ Foundation 'Beauregard' = virus-infected transplants; B-63 G-1 = first-year greenhouse-grown virus-tested (no detected viruses) transplants; B-63 G-2 = second-year field-grown transplants; B-63 G-3 = third-year field-grown transplants; B-63 G-4 = fourth-year field-grown transplants.

y $1 \mathrm{bu} / \mathrm{acre}=56 \mathrm{~kg} \cdot \mathrm{ha}^{-1}$; U.S. no. $\mathrm{l}$ : roots $2-3.5$ inches $(5.1-8.9 \mathrm{~cm})$ diameter and 3 to 9 inches $(7.6-22.9 \mathrm{~cm})$ long; canner: roots $1-2$ inches $(2.5-5.1 \mathrm{~cm})$ diameter; $2-7$ inches $(5.1-17.8 \mathrm{~cm})$ long; jumbo: larger than either of the others, but marketable; total marketable (U.S. \#1 + canner + jumbo).

Number of plots containing treatment.

weast squares mean separation within columns by $t$ test, $P \leqq 0.05$. 
Clark, C.A. 2001. Viruses and sweetpotato cultivar decline in Louisiana, USA, p. 62-69. In: Y. Nakazawa and K. Ishiguro (eds.). Intl. Wkshp. Sweetpotato Cultivar Decline. Kyushu National Agr. Expt. Sta., Miyakonojo, Miyazaki, Japan.

Miller, J.C., T.P. Hernandez, and R.J. Barry, Jr. 1959. Sweet potato foundation seed program for Louisiana. Louisiana Agr. Expt. Stn. Circ. No. 58.

Moyer, J.W. and C.A. Clark. 1988. Compendium of sweet potato diseases. APS Press, St. Paul, Minn.

Souto, E.R., J. Sim, J. Chen, R.A. Valverde, and C.A. Clark. 2003. Properties of strains of sweetpotato feathery mottle virus and two newly recognized potyviruses infecting sweetpotato in the United States. Plant Dis. 87:1226-1232.

Villordon, A.Q., J.M. Cannon, H.L. Carroll, and J.W. Franklin. 2003. Sweetpotato 'Beauregard' mericlones vary in yield, vine characteristics, and storage root size and shape attributes. HortScience 38:1089-1092. 